九州大学学術情報リポジトリ

Kyushu University Institutional Repository

\title{
Preparations of Histone and Nucleosome
}

\section{Yamada, Koj i}

Institute of Food Chemistry, Faculty of Agriculture, Kyushu University

Murakami, Hiroki

Institute of Food Chemistry, Faculty of Agriculture, Kyushu University

Shi rahata, Sanetaka

Institute of Food Chemistry, Faculty of Agriculture, Kyushu University

Nishiguchi, Hisashi

Institute of Food Chemistry, Faculty of Agriculture, Kyushu University

他

https://doi.org/10.5109/23666

出版情報：九州大学大学院農学研究院紀要. 22 (4)，pp.203-210，1978-07. Kyushu University バージョン：

権利関係: 


\title{
Preparations of Histone and Nucleosome
}

\section{Koji Yamada. Hiroki Murakami, Sanetaka Shirahata, Hisashi Nishiguchi, Kazuki Shinohara and Hirohisa Omura}

\author{
Institute of Food Chemistry, Faculty of Agriculture, \\ Kyushu University 46-09, Fukuoka 812
}

(Received January 13, 1978)

\begin{abstract}
In eukaryote cells chromatin is composed of DNA, histone and nonhistone proteins. Among them histone was isolated from chromatin by the replacement with protamine. followed by a gel filtration for the separation of whole histone from the residual protamine. Whole histone was further fractionated to two fractions, $A$ and $B$. These histone preparations were more native and soluble than that obtained by acid extraction. A DNA-protein complex, nucleosome was prepared by the DNase II digestion of calf thymus chromatin, but perfect digestion to nucleosome monomer could not be carried out. Protein: DNA ratio of this nucleosome (2.07) suggested that nonhistone proteins were also present in nucleosome.
\end{abstract}

\section{INTRODUCTION}

Catecholamines (CA) such as adrenaline, which were enzymatically synthesized from tyrosine and phenylalanine, can break chromatin DNA in cultured mammalian cells (Murakami et al., 1975). On the other hand, "C-adrenaline added in culture medium was incorporated into cells. That most of incorporated adrenaline was detected in nucleus especially in DNA fraction, suggested a possibility that these CA could attack directly to break cellular chromatin DNA (Yamada et al., 1978). Since in eukaryote cells DNA exists in the form of chromatin which is composed of DNA, histone and nonhistone proteins, interactions between CA and these chromatin components must be clarified. Thus separations of histone and nucleosome, a DNA-protein complex, were carried out.

Acid extraction have been used for the preparation of histone (Bonner et al., 1968). However it was necessary to use more mild preparative method because of denaturation being inevitable in this method. In this paper histone was prepared mainly according to the method of Westhuyzen and Holt (1971). On the other hand it has been thought that chromatin might have a repeated structure according to its X-ray diffraction pattern (Zubay and Wilkins, 1962) or electron microscopic study (Olins and Olins, 1974). The presense of this ordered structure was ascertained by DNase digestion of chromatin; i. e. an unit particle with a sedimentation coefficient between 11 to $12 \mathrm{~S}$ could be obtained by the treatments of chromatin with various DNases (Noll, 1974). In this paper the results of DNase II digestion of calf thymus 
chromatin were shown.

\section{MATERIALS AND METHOD}

\section{Reagents}

Since protamine sulfate (Sigma) contains histonelike impurities, it was used after a recrystalization in a mixture of $0.05 \mathrm{M} \mathrm{CH}_{3} \mathrm{COONa}, 0.05 \mathrm{M}$ $\mathrm{NaHSO}_{3}$ and $2 \mathrm{M} \mathrm{NaCl}$. DNase II (250 units/mg) was purchased from MilesSeravac Co. and all other chemicals used were reagent grade.

\section{Preparation of histone}

Calf thymus obtained from a slaughter house was immediately frozen, then the tissue weighing $50 \mathrm{~g}$ was dissected in the cold room to remove any connective and necrotic tissue and then cut into small pieces, followed by a homogenation in $250 \mathrm{ml}$ of $\mathrm{C}$-buffer $(0.14 \mathrm{M} \mathrm{NaCl}, 0.01 \mathrm{M}$ trisodium citrate, 0. $05 \mathrm{M} \mathrm{NaHSO}_{3}$ ) with Waring blender. Homogenate was filtered through four layer gauze, and filtrate was then centrifuged for $15 \mathrm{~min}$ at $15 \mathrm{OOg}$ to precipitate the chromatin fraction. After rinsing several times with C-buffer, chromatin was suspended in $100 \mathrm{ml}$ of a mixture of $\mathbf{0}$. $10 \mathrm{M} \mathrm{NaHSO}_{3}$ and $0.10 \mathrm{M}$ $\mathrm{CH}_{3} \mathrm{COONa}$ (pH 5.0). Then $100 \mathrm{ml}$ of $4 \mathrm{M} \mathrm{NaCl}$ was gradually added to the solution to solubilyze chromatin while agitating with a magnetic stirrer. Supernatant obtained after centrifugation for $20 \mathrm{~min}$ at $10,000 \mathrm{~g}$ was used as chromatin solution in following experiments. This chromatin solution (ca. $4 \mathrm{mg} /$ $\mathrm{ml}$ ) was mixed with an equal volume of protamine solution (ca. $20 \mathrm{mg} / \mathrm{ml}$ ). The buffer of the chromatin solution was replaced by C-buffer containing $0.15 \mathrm{M} \mathrm{NaCl}$ to precipitate its DNA-protamine complex, since the complex was insoluble to the saline solution. Then the supernatant was obtained by the centrifugation at $10,000 \mathrm{~g}$ for $20 \mathrm{~min}$. Absence of DNA in the supernatant was confirmed by the measurement of the absorption at $260 \mathrm{~nm}$. The histone-protamine mixture thus obtained was fractionated with a Sephadex G50 column $(3.7 \times 90 \mathrm{~cm})$ bufferized with a mixture $0.05 \mathrm{M} \mathrm{NaHSO}_{3}$ and $0.05 \mathrm{M}$ $\mathrm{CH}_{3} \mathrm{COONa}(\mathrm{pH}$ 5.0) to remove protamine. Histone fraction was concentrated with a collodion bag and further divided into fraction $A$ and $B$ with a Sephadex G-100 filter $(2.5 \times 95 \mathrm{~cm})$ equilibrated with the same buffer.

\section{Estimation of histone}

Whole histone solution obtained above was dialyzed to deionized water to remove any salts and lyophilyzed. The known weight histone was dissolved in $0.1 \mathrm{~N} \mathrm{HCl}$ to make a calibration curve by the measurement of the absorption at $230 \mathrm{~nm}$. By the use of histone sulfate, which was extracted directly from chromatin pellet with $0.2 \quad \mathrm{~N} \mathrm{H}_{2} \mathrm{SO}_{4}$ then prepared by ethanol precipitation, a calibration curve was also described.

Preparation of nucleosome

Nucleosome was prepared according to the method of Oosterhof et al. (1975). Five $\mathrm{ml}$ of chromatin solution was layered on a centrifugal tube con- 
taining $25 \mathrm{ml}$ of $1.7 \mathrm{M}$ sucrose and centrifuged at $22,000 \mathrm{rpm}$ for $3 \mathrm{hr}$ with Beckman SW-25 rotor to further purify. After several times of rinsing with D-buffer $\left(5 \mathrm{mM} \mathrm{NaHSO}_{3}, \quad 0.1 \mathrm{mM} \mathrm{Na}_{2}\right.$ EDTA, adjusted pH at 7.0 with solid Tris), chromatin was suspended in the same buffer resulted in the concentration of $200 \mu \mathrm{g} / \mathrm{ml}$ with regard to DNA. One tenth volume of DNase II solution (100 units $/ \mathrm{ml}$ ) was added to this suspension and incubated at $37^{\circ} \mathrm{C}$. Reaction mixture was added into an equal volume of S-buffer $\left(5 \mathrm{mM} \mathrm{NaHSO}_{3}\right.$, $0.1 \mathrm{mMNa}_{2} \mathrm{EDTA}, 50 \mathrm{mM}$ Tris) to terminate the enzymatic digestion.

Process of the digestion was followed by the measurements of the absorptions at $260 \mathrm{~nm}$ of soluble and acid soluble fractions. One $\mathrm{ml}$ of the reaction mixture was added into $4 \mathrm{ml}$ of S-buffer, followed by centrifugation at $3,000 \mathrm{~g}$ for $10 \mathrm{~min}$ to obtain its supernatant (soluble fraction). Another one $\mathrm{ml}$ was added into $4 \mathrm{ml}$ of $5 \% \mathrm{PCA}$, the mixture was stood for $30 \mathrm{~min}$ at $0^{\circ} \mathrm{C}$ and centrifuged at $3,000 \mathrm{~g}$ for $10 \mathrm{~min}$ (acid soluble fraction). To examine the molecular size of nucleosome, $0.4 \mathrm{ml}$ of digest was layered on the top of $4.6 \mathrm{ml}$ of $5-20 \%$ sucrose density gradient, followed by centrifugation at 40,000 rpm for $5 \mathrm{hr}$ with Beckman SW-50 rotor. Gradient buffer used was the mixture of $5 \mathrm{mM} \mathrm{Na}_{2} \mathrm{HSO}_{3}, 0.1 \mathrm{mM} \mathrm{Na}_{2} \mathrm{EDTA}$ and $25 \mathrm{mM}$ Tris.

Chromatin digest obtained above was centrifuged at $10,000 \mathrm{~g}$ for $20 \mathrm{~min}$ to remove any insoluble materials. After addition of $2 \mathrm{M} \mathrm{NaCl}$ (final concentration, $0.14 \mathrm{M}$ ) this supernatant was stood at $0^{\circ} \mathrm{C}$ for $30 \mathrm{~min}$. The nucleosome fraction precipitated was collected by centrifugation, then extracted with $10 \mathrm{mM}$ acetate buffer ( $\mathrm{pH} \mathrm{7.0).} \mathrm{About} 20 \%$ of starting nucleic acid was recovered in this nucleosome solution.

\section{Determination of protein: DNA ratio in nucleosome}

One ml of $1 \mathrm{~N} \mathrm{H}_{2} \mathrm{SO}_{4}$ was mixed with $4 \mathrm{ml}$ of the nucleosome solution to precipitate the DNA. After standing at $0^{\circ} \mathrm{C}$ for $30 \mathrm{~min}$, this mixture was centrifuged at $10,000 \mathrm{~g}$ for $20 \mathrm{~min}$. The content of basic protein which existed in the supernatant was quantitatively estimated by the use of the calibration curve prepared above. Precipitate was dissolved in $5 \mathrm{ml}$ of $10 \mathrm{mM}$ acetate buffer ( $\mathrm{pH}$ 7.0) to determine the DNA content by the absorption at $260 \mathrm{~nm}$.

\section{RESULTS AND DISCUSSION}

\section{Preparation of histone}

Frozen chromatin pellet was difficult to re-suspend for its remarkable aggregation which lowered the recovery of histone. Thus immediately after the preparation of chromatin, histone was separated. When the $\mathrm{NaCl}$ concentration in the mixture of chromatin and protamine was lowered from 2. OOM to $0.15 \mathrm{M}$ by the dialysis against the buffer containing $0.15 \mathrm{M} \mathrm{NaCl}$, DNA-protamine complex precipitated to the bottom of dialysing tube. The result of Sephadex G-50 separation of the supernatant obtained from dialyzed solution was shown in Fig. 1. Histone eluted first giving a sharp peak and protamine gave a broad one in lower molecular region. Though Westhuyzen 


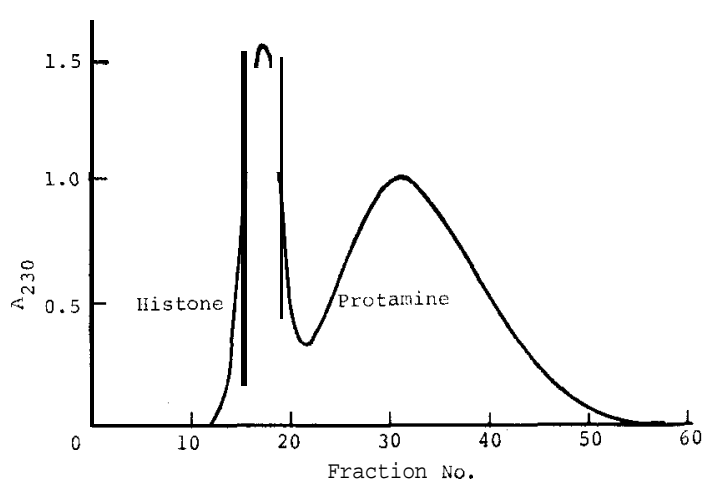

Fig. 1. Gel filtration on Sephadex G-50 of a mixture of histones and protamine obtained after precipitation of DNA by protamine. A $50 \mathrm{ml}$ sample was applied to Sephadex G-50 equilibrated with $0.05 \mathrm{M} \mathrm{NaHSO}_{3}$, $0.05 \mathrm{M} \mathrm{CH} \mathrm{CH}_{3} \mathrm{CONa}(\mathrm{pH}$ 5.0). Bed dimensions: 3.7 90 $\mathrm{cm}$. Flow rate : 300 $\mathrm{ml} / \mathrm{hr}$. Fraction volume : $10 \mathrm{ml}$.

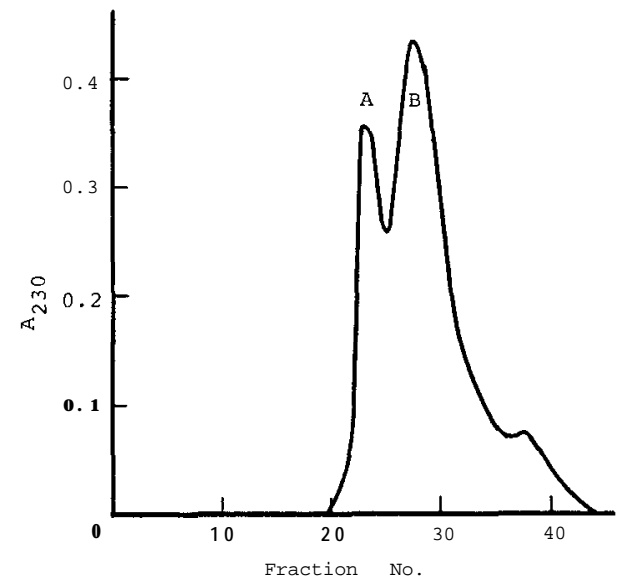

Fig. 2. Gel filtration on Sephadex G-100 of histones from calf thymus. A $5 \mathrm{ml}$ sample was applied to Sephadex G-100 equilibrated with $0.05 \mathrm{M}$ $\mathrm{NaHSO}_{3}, 0.05 \mathrm{M} \mathrm{CH}_{3} \mathrm{COONa}(\mathrm{pH}$ 5.0). Bed dimensions: 2.5 $95 \mathrm{~cm}$. Flow rate $: 15 \mathrm{ml} / \mathrm{hr}$. Fraction volume $: 6 \mathrm{ml}$.

and Holt (1971) had concentrated this histone fraction by freeze-drying, we concentrated it with a collodion bag at $5^{\circ} \mathrm{C}$ because of the aggregation of histone as well as chromatin, after freezing. By the Sephadex G-100 separation of this concentrated solution histone was fractionated to two fractions, $\mathrm{A}$ and $\mathrm{B}$ as shown in Fig, 2. Fraction A contains $\mathrm{H} 1, \mathrm{H} 3$ and $\mathrm{H} 4$ and fraction B contains H2A and H2B (Kornberg and Thomas, 1974). Since much the same weight of these five histones exist in chromatin (Johns. 1967), weight ratio of fraction $\mathrm{A}$ to $\mathrm{B}$ in chromatin is expected to be about 1.5. However in the result of Sephadex G-100 fractionation it was about 0.6. This low recovery of fraction A can be attributed to following reasons. The first 
reason would be the loss of $\mathrm{H} 1$ during chromatin preparation because of its weak binding ability to DNA (Akinrimisi et al., 1965). On the other hand, strong binding abilities of $\mathrm{H} 3$ and $\mathrm{H} 4$ to DNA would result in low recovery during isolation of histone. When DNA was precipitated with protamine, small amounts of $\mathrm{H} 3$ and $\mathrm{H} 4$ were detected in the precipitate, but none of $\mathrm{H} 1$, H2A and H2B (Westhuyzen and Holt, 1974). Moreover stronger aggregation of $\mathrm{H} 3$ and $\mathrm{H} 4$ also lowers the recovery of them. Kornberg and Thomas (1974) revealed that $\mathrm{H} 3$ and $\mathrm{H} 4$ were more tend to form big coaggregates than $\mathrm{H} 2 \mathrm{~A}$ and $\mathrm{H} 2 \mathrm{~B}$. In prolonged reservations at $5^{\circ} \mathrm{C}$, some precipitate occurred in fraction A but none in fraction B. Formation of these big aggregates would hamper the recovery of the former during Sephadex gel filtrations. In the fractionations using Sephadex gel, the recovery of histone was only 70 to $80 \%$. Histone fraction retained in the gel eluted with $0.1 \mathrm{~N} \mathrm{HCl}$. Since denaturation of histone being inevitable at such a low $\mathrm{pH}$, however, resulted in lower solubility and more aggregation, elution of histone was carried out at $\mathrm{pH} 5.0$.

Calibration curve of histone was prepared using whole histone obtained after Sephadex G-50 separation, as shown in Fig. 3. Histone has little absorption at $280 \mathrm{~nm}$ for its low content of aromatic amino acids and has a peak at $210 \mathrm{~nm}$ based on peptide bonds. Since some of buffer components also gave an absorption in the vicinity of $200 \mathrm{~nm}$, histone was determined by its absorption at $230 \mathrm{~nm}$. Whole histone solution $\left(\mathrm{mg} / \mathrm{ml}\right.$ ) gave an $A_{230}$ value, 2.35, which was equal to that of histone prepared by acid extraction. Since this absorption is based on peptide bond, it would not be influenced with denaturation of histone.

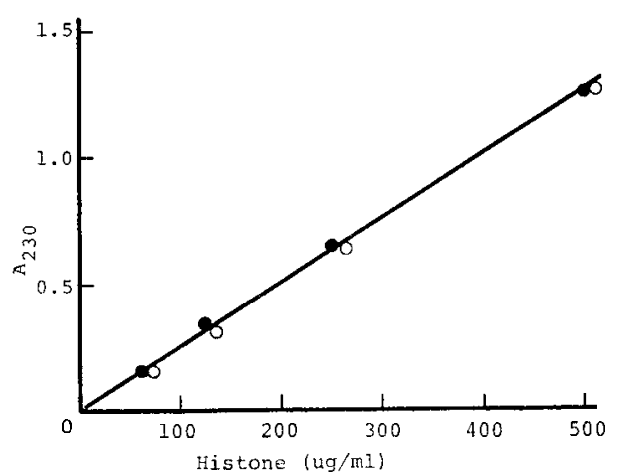

Fig. 3. Calibration curves of histones. Dried whole histone obtained by Sephadex G-50 separation was dissolved in 1 N HCI to measure the absorption at $230 \mathrm{~nm}$, - $-\mathrm{m}$. Histone sulfate obtained by acid extraction was also dissolved in deionized water to describe a calibration curve, o-o.

\section{Preparation of nucleosome}

Calf thymus chromatin was quickly digested by DNase II and solubilyzed almost perfectly by a 2 hour-digestion. Following slower increase in the absorption at $260 \mathrm{~nm}$ of the soluble fraction would be due to hyperchromisity 


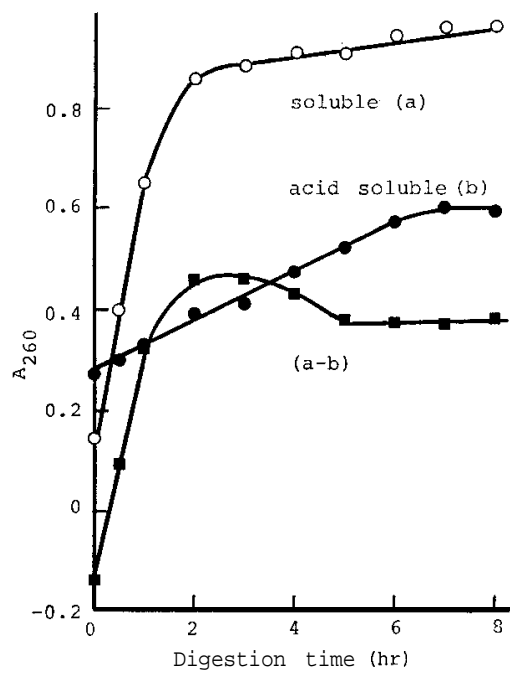

Fig. 4. DNase II digestion of chromatin from calf thymus. Chromatin solution containing $200 \mu \mathrm{g} / \mathrm{ml}$ of DNA was mixed with one tenth volume of DNase II solution ( 100 units $/ \mathrm{ml}$ ) and incubated at $37^{\circ} \mathrm{C}$. Aliquots of the digested solution were added to $4 \mathrm{ml}$ of S-buffer or $5 \%$ PCA, then the mixtures were centrifuged at $3000 \mathrm{~g}$ for $10 \mathrm{~min}$ with or without incubation at $0^{\circ} \mathrm{C}$ for $30 \mathrm{~min}$.

occurred by the breakage of phosphodiester linkage of DNA, since the fragmentation of DNA compensated the hypochromisity provoked by the basal stacking in highly polymerized DNA. On the other hand, the acid soluble fraction increased linearly with reaction time and reached to the maximum after $7 \mathrm{hr}$, when the acid soluble material in the reaction mixture reached about $60 \%$ of the total nucleic acid. Difference between soluble and acid soluble materials represents higher molecular substances in the digestion mixture. It gave the maximum after 2-3 hour incubation, and then indicated an almost constant value after a little decrease (Fig. 4).

The ultracentrifugal pattern of the digestion mixture which was treated for $8 \mathrm{hr}$ was shown in Fig. 5. Although monomer peak appeared at fraction 17, oligomer peaks containing dimer to pentamer also existed. Nucleosome was precipitated from this 8 hour digested solution by the addition of $2 \mathrm{M} \mathrm{NaCl}$ (final concentration, $0.15 \mathrm{M}$ ) and re-extracted with $10 \mathrm{mM}$ acetate buffer. In this extract low molecular components over fraction 20 were not present at all. However weak shift of the peaks of nucleosome to higher molecular side suggested that nucleosome slightly aggregated during this precipitation. Since the same polymerization was recognized remarkably when the digested solution was freezed and thawed, freeze-reservation of the solution should not be favored,

Protein: DNA ratio of this nucleosome was 2.07. The value was fairly consistent with the result obtained by Lacy and Axel (1975) who reported that protein: DNA ratio of rat liver nucleosome was 2.0 and only $60 \%$ of its 


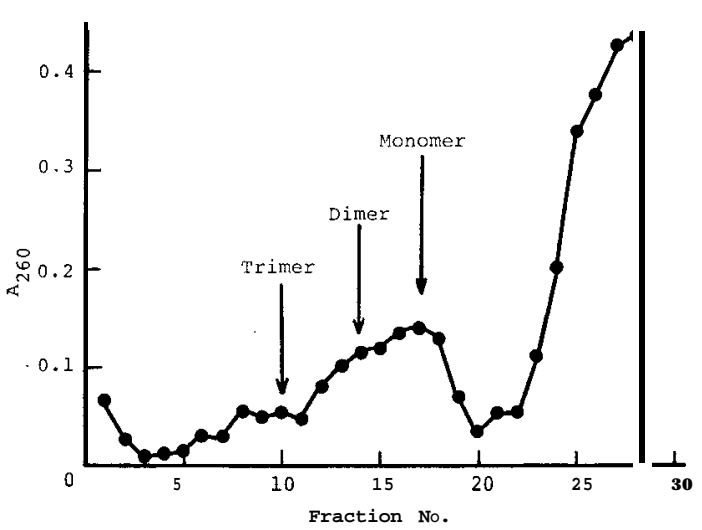

Fig. 5. Sedimentation pattern of DNase II digested calf thymus chromatin. $0.4 \mathrm{ml}$ of reaction mixture digested for $8 \mathrm{hr}$ was put on the top of $5-20 \%$ sucrose density gradient $(4.6 \mathrm{ml})$, followed by centrifugation at 40,000 rpm for $5 \mathrm{hr}$ with Backman SW-50 rotor. After centrifugation, DNA content of each fraction was determined with Hitachi Photo-electronic Spectrophotometer. The sedimentation was from right to left of this figure.

protein was histone. Accroding to the data of Noll (1974) using rat liver nucleosome similarly, however, the ratio was 1.3 and its protein was composed of all five histones and a little of nonhistone proteins. Other experiments also showed it 1.3-2. 0 (Rill and Van Holde, 1973; Sahasrabuddhe and Van Holde, 1974). In these data histone content is almost constant, but that of nonhistone protein is very variable. Our result suggested that the subunits contained nonhistone proteins in amounts analogous to that of intact chromatin. The protein complement of the isolated nucleosome therefore mirrors the pattern observed in the native chromatin from which the subunits were originally isolated.

As shown above, $60 \%$ of the total nucleic acid in chromatin became to be acid soluble by the DNase II digestion for $8 \mathrm{hr}$. However even in this condition, perfect digestion to monomer was not occurred. The relationship between the acid solubility and the grade of degradation of chromatin was different with the nuclease used; The maximum of the acid solubility of chromatin was $60 \%$ in DNase II (Oosterhof et al., 1975), $10 \%$ in staphylococcal nuclease (Mandel and Fasman, 1976) and $21.5 \%$ in micrococcal nuclease (Olins et al., 1976). The disagreement of these data on the acid solubility might be due to the degree of digestion of the DNA moiety which linked nucleosomes each other. It supports the presumption that nucleosome monomers obtained by the digestion with various nucleases have almost the same sedimentation coefficient (11-12S), but the lengths of their DNA vary from 105 to 180 base pairs.

\section{REFERENCES}

Akinrimisi, E. O., J. Bonner and P. 0. P. Ts'o 1965 Binding of basic proteins to DNA. 
J. Mol. Biol., $11:$ 128-136

Bonner et al. 1968 Isolation and chracterization of chromosomal nucleoproteins. In "Methods in Enzymology," Vol. 12 B, ed. by L. Grossman and K. Moldave. Academic Press, Inc., New York, pp. 3-65

Johns, E. W. 1967 The electrophoresis of histones in polyacrylamide gel and their quantitative determination. Biochem. J., $104: 78-82$

Kornberg. R. D. and J. 0. Thomas 1974 Chromatin structure: Oligomers of the histones. Science, $184: 865-868$

Lacy, E. and R. Axel 1975 Analysis of DNA of isolated chromatin subunits. Proc. Natl. Acad. Sci. USA, 12: 3978-3982

Mandel, R. and G. D. Fasman 1976 Chromatin and nucleosome structure. Nuc. Acids Res., 3: 1839-1855

Murakami, H., T. Miyoshi, M. Koga. K. Yamada and H. Omura 1975 Breakage of chromosomal DNA with aromatic reductones. Agric. Biol. Chem.. 39: 795-801

Noll, M. 1974 Subunit structure of chromatin. Nature, 251: 249-251

Olins, A. L. and D. E. Olins 1974 Spheroid chromatin units ( $\nu$ bodies). Science, 183: 330332

Olins, A. L., R. D. Carlson, E. B. Wright and D. E. Olins 1976 Chromatin $\nu$ bodies: Isolation, subfractionation and physical characterization. Nuc. Acids Res., 3 : 3271-3291

Oosterhof, D. K., J. C. Hazier and R. L. Rill 1975 Nuclease action on chromatin: Evidence for discrete, repeated nucleoprotein units along chromatin fibrils. Proc. Natl. Acad. Sci. USA, 12: 633-637

Kill, R. and K. E. Van Holde 1973 Properties of nuclease-resistant fragments of calf thymus chromatin. J. Biol. Chem., 248: 1080-1083

Sahasrabuddhe, C. G. and K. E. Van Holde 1974 The effect of trypsin on nuclease-resistant chromatin fragment. J. Biol.Chem., 249: 152-156

Westhuyzen. D. R. van der and C. von Holt 1971 A new procedure for the isolation and fractionation of histones. FEBS Letters, 14 : 333-337

Yamada, K., H. Murakami, S. Shirahata and H. Omura 1978 Intranuclear incorporation and binding to chromosomal DNA of epinephrine. Agric. Biol.Chem., 42: 45-48.

Zubay, G. and M. H. F. Wilkins 1962 An X-ray diffraction study of histone and protamine in isolation and in combination with DNA. J. Mol. Biol., 4: 444-450 